\title{
Estrogen Regulates Functional Inhibition of Hippocampal CA1 Pyramidal Cells in the Adult Female Rat
}

\author{
Charles N. Rudick and Catherine S. Woolley \\ Department of Neurobiology and Physiology and Northwestern University Institute for Neuroscience, Northwestern \\ University, Evanston, Illinois 60208
}

\begin{abstract}
Previous studies have focused considerable attention on the effects of estrogen on excitatory synaptic input to hippocampal CA1 pyramidal cells. Estrogen increases the density of dendritic spines and synapses on CA1 pyramidal cells and increases the sensitivity of these cells to excitatory synaptic input. Little is known, however, about the effects of estrogen on inhibitory synaptic input to CA1 pyramidal cells. We have used immunohistochemistry for glutamic acid decarboxylase and whole-cell voltage-clamp recording of IPSCs and EPSCs at multiple time points after estrogen treatment to (1) investigate estrogen regulation of synaptic inhibition in CA1 and (2) evaluate how estrogen affects the interaction between inhibitory and excitatory input to CA1 pyramidal cells. We find that estrogen transiently suppresses $G_{A B A}$-mediated inhibition of CA1 pyramidal cells
\end{abstract}

Previous studies have shown that estrogen induces structural and functional changes in excitatory input to hippocampal CA1 pyramidal cells in adult female rats. Estrogen increases the density of dendritic spines (Gould et al., 1990; Woolley and McEwen, 1993; Woolley et al., 1997; McEwen et al., 1999) and spine synapses (Woolley and McEwen, 1992; Woolley et al., 1996; Leranth et al., 2000) on CA1 pyramidal cells. These structural changes in excitatory input are paralleled by increases in synaptic excitability of CA1 pyramidal cells, particularly synaptic input mediated by the NMDA subtype of the glutamate receptor (Weiland, 1992; Wong and Moss, 1992; Gazzaley et al., 1996; Woolley et al., 1997).

Although considerable attention has been focused on the effects of estrogen on excitatory synaptic input to CA1 pyramidal cells, little is known about the effects of estrogen on inhibitory input to these cells. Interestingly, studies of the effects of estrogen on dendritic spine density on cultured hippocampal neurons have shown that estrogen increases spine density via an activitydependent mechanism that requires transient suppression of GABAergic inhibitory synaptic transmission (Murphy et al., 1998). Several parallels between estrogen regulation of spine density in vitro and in vivo suggest that similar mechanisms may be involved. Both effects require several days of estrogen exposure (Woolley and McEwen, 1993; Murphy and Segal, 1996), and both

\footnotetext{
Received Feb. 13, 2001; revised June 18, 2001; accepted June 21, 2001.

This work was supported by National Institute of Neurological Disorders and Stroke Grant NS37324 and by the Alfred P. Sloan Foundation. C.N.R. was supported by National Institutes of Health Training Grant GM08061. We thank Drs. Nelson Spruston and Indira Raman for help with experimental setup and for their critical reading of this manuscript.

Correspondence should be addressed to Dr. Catherine S. Woolley, Department of Neurobiology and Physiology, Northwestern University, 2153 North Campus Drive, Evanston, IL 60208. E-mail: cwoolley@northwestern.edu.

Copyright (C) 2001 Society for Neuroscience $0270-6474 / 01 / 216532-12 \$ 15.00 / 0$
}

at a time point before changes in excitatory input to these cells occur. This finding is consistent with the suggestion that transient disinhibition of CA1 pyramidal cells is involved in estrogen-induced dendritic spine formation. We have also found that at a later time after estrogen, inhibition of CA1 pyramidal cells recovers in parallel with enhancement of NMDA-mediated excitatory input. The concurrent enhancement of $\mathrm{GABA}_{\mathrm{A}}$ and NMDA-mediated input to CA1 pyramidal cells restores a balance of excitatory and inhibitory input to these cells and increases the potential dynamic range of CA1 pyramidal cell responses to synaptic input.

Key words: GABA; glutamic acid decarboxylase; IPSCs; AMPA; NMDA; seizures

are blocked by NMDA receptor antagonists (Woolley and McEwen, 1994; Murphy and Segal, 1996) and antagonists of classical estrogen receptors (Murphy and Segal, 1996; McEwen et al., 1999). The possibility that changes in GABAergic neurotransmission are involved in estrogen regulation of spine density in the hippocampus in vivo is supported by the observation that most hippocampal neurons that express classical estrogen receptors are GABAergic interneurons [in the dorsal hippocampus, where spine changes occur (Weiland et al., 1997; Hart and Woolley, 2000)].

The goals of the current study were to (1) determine whether estrogen regulates GABAergic synaptic transmission in vivo as it does in vitro and (2) determine the relationship between inhibitory and excitatory synaptic transmission in the CA1 region at two time points within the estrogen treatment protocol known to regulate dendritic spines. One time point was chosen to be before estrogen-induced spine density changes occur, and one time point was after estrogen-induced differences in spine density are established [based on previous studies (Woolley and McEwen, 1993)]. We used immunohistochemistry for glutamic acid decarboxylase (GAD), the rate-limiting enzyme in GABA synthesis, and wholecell voltage-clamp recording of IPSCs and EPSCs in CA1 pyramidal cells to show the following. (1) Estrogen transiently decreases GABAergic inhibition of these cells. This disinhibition results in enhancement of excitatory synaptic input at a time before spine changes occur. (2) At a later time, when spine density is increased in estrogen-treated animals, GABAergic inhibition is also increased. The counteracting effects of estrogen on inhibitory and excitatory input at the later time point restore a balance of excitatory and inhibitory input to CA1 pyramidal cells and also potentially increase the dynamic range of the responses of these cells to synaptic input. 


\section{MATERIALS AND METHODS}

Animals and hormone treatment. Adult female Sprague Dawley rats (180-220 gm) were housed on a $12 \mathrm{hr}$ light/dark cycle with food and water available ad libitum. All rats were bilaterally ovariectomized (OVX) under methoxyflurane anesthesia using aseptic procedures. On the third only or third and fourth days after surgery, rats were injected subcutaneously either with $10 \mu \mathrm{g}$ of $17 \beta$-estradiol benzoate in $100 \mu \mathrm{l}$ of sesame oil (E) or with $100 \mu \mathrm{l}$ of sesame oil alone (O) and allowed to survive for various times after injection.

The densities of GAD65- and GAD67-immunoreactive cells were quantified at the following time points (Fig. $1 A)(n=6$ for all groups): $3 \mathrm{~d}$ OVX (3DO; before any injections), 2 or $24 \mathrm{hr}$ after the first $\mathrm{O}$ injection $\left(2{ }^{1} \mathrm{O}\right.$ and $\left.24{ }^{1} \mathrm{O}\right)$ or $\mathrm{E}$ injection $\left(2{ }^{1} \mathrm{E}\right.$ and $\left.24{ }^{1} \mathrm{E}\right), 48 \mathrm{hr}$ after the second $\mathrm{O}$ injection $\left(48^{2} \mathrm{O}\right)$, and 2 and $48 \mathrm{hr}$ after the second $\mathrm{E}$ injection $\left(2^{2} \mathrm{E}\right.$ and $\left.48^{2} \mathrm{E}\right)$. Surgeries and treatment times were staggered so that all animals were perfused together. IPSCs and EPSCs in CA1 pyramidal cells were recorded in slices from animals killed at the $3 \mathrm{DO}, 24^{1} \mathrm{O}, 24^{1} \mathrm{E}$, $48^{2} \mathrm{O}$, and $48^{2} \mathrm{E}$ time points (Fig. $1 A$ ).

Immunohistochemistry. All rats were deeply anesthetized with Nembutal $(80 \mathrm{mg} / \mathrm{kg})$ and transcardially perfused with cold $4 \%$ paraformaldehyde in $0.1 \mathrm{M}$ phosphate buffer (PB), $\mathrm{pH}$ 7.4. After perfusion, brains were removed, blocked, and post-fixed overnight in the same solution at $4^{\circ} \mathrm{C}$. The brains were rinsed with $0.1 \mathrm{M} \mathrm{PB}$, cryoprotected in $30 \%$ sucrose, and coronally sectioned through the dorsal hippocampus $(50 \mu \mathrm{m})$ using a freezing microtome. Sections were stained immunohistochemically using the avidin-biotin-peroxidase method described below. Sections from each brain were processed for GAD65 (monoclonal to rat GAD 65 $\mathrm{kDa}$ isoform; Chemicon, Temecula, CA) or GAD67 (polyclonal to rat GAD $67 \mathrm{kDa}$ isoform; Chemicon).

Freshly cut sections were rinsed in PB and incubated in $1 \%$ sodium borohydride for $10 \mathrm{~min}$, rinsed, and then incubated in $\mathrm{H}_{2} \mathrm{O}_{2}(0.5 \%$ for 30 min, $1.0 \%$ for $1 \mathrm{hr}$, and $0.5 \%$ for $30 \mathrm{~min}$ ). After rinsing in Tris buffer (TB), $\mathrm{pH} 7.4$, sections were incubated for $1 \mathrm{hr}$ in a nonspecific blocking solution containing 5\% normal serum, $3 \%$ bovine serum albumin (BSA), and $0.3 \%$ dimethylsulfoxide (DMSO) in $0.5 \mathrm{M}$ Tris-buffered saline (TBS). Sections were then rinsed and incubated in the primary antibody or antisera $(2 \mu \mathrm{g} / \mathrm{ml}$ for GAD65 or 1:10,000 for GAD67) solution containing $1 \%$ normal serum, $3 \%$ BSA, and $0.3 \%$ DMSO for $48 \mathrm{hr}$ at $4^{\circ} \mathrm{C}$ in $0.5 \mathrm{M}$ TBS. Some sections from each brain were incubated without the primary to determine nonspecific secondary antibody staining.

After primary incubation, sections were rinsed thoroughly with $0.1 \mathrm{M}$ TBS and incubated in biotinylated secondary antibody (1:400; antimouse IgG for GAD65 or anti-rabbit IgG for GAD67) solution containing $1 \%$ normal serum, $2 \%$ BSA, and $0.3 \%$ DMSO in $0.1 \mathrm{~m} \mathrm{TBS}$ for $3 \mathrm{hr}$. The sections were rinsed with $0.1 \mathrm{M}$ TBS and incubated in avidin-biotin HRP complex (1:500; Vector Elite Kit) for $3 \mathrm{hr}$. Next, the sections were rinsed and preincubated in $\mathrm{TB}, \mathrm{pH} 7.6$, containing $0.025 \% 3,3^{\prime}$ diaminobenzidine for $20 \mathrm{~min}$ followed by addition of $0.01 \% \mathrm{H}_{2} \mathrm{O}_{2}$ for an additional $20 \mathrm{~min}$. Finally, the sections were rinsed, mounted onto subbed slides, dried, dehydrated in graded ethanols, cleared in xylene, and coverslipped under Permount.

Quantification of GAD65- and GAD67-labeled cells. Tissue sections for quantitative analysis of GAD-immunoreactive cells were coded, and the code was not broken until analysis was complete. Unbiased estimates of the density of GAD65- and GAD67-labeled cells were obtained using the optical disector principle and random systematic sampling (Gundersen et al., 1988). For both left and right sides of each brain, 10 sectors $(184 \times$ $246 \mu \mathrm{m}$ ) were randomly chosen for each layer of the CA1 region. Four nonadjacent tissue sections were analyzed for each brain. The starting point for cell counting was set at $5 \mu \mathrm{m}$ below the surface of the section and stepped down five times at $2 \mu \mathrm{m}$ per step for a total of $10 \mu \mathrm{m}$. Labeled cells that were sharply in focus and inside the counting frame or that intersected the upper horizontal and right vertical were counted at each step; cells that intersected the left vertical and lower horizontal of the counting frame were not counted. Labeled cells were visualized with a $50 \times$ oil-immersion lens on an Olympus BX60 microscope (Olympus Optical, Tokyo, Japan) with a Dage DC330 camera (Dage MTI, Inc., Michigan City, IN) and Image-Pro Plus software (Media-Cybernetics, Silver Spring, MD). The density of labeled cells was calculated by dividing the sum of all cells counted by the volume of all disectors counted. Means were calculated for each animal, and the data were analyzed statistically using ANOVA with Tukey post hoc comparisons.

Slice preparation and maintenance. On each recording day, two animals (one control and one estrogen-treated) were coded, and the code was not broken until all data analysis for those animals was complete. All rats used for electrophysiological recordings were anesthetized with Nembutal $(80 \mathrm{mg} / \mathrm{kg})$ and transcardially perfused with ice-cold oxygenated (95\% $\mathrm{O}_{2} / 5 \% \mathrm{CO}_{2}$ ) artificial CSF (ACSF) containing (in $\mathrm{mM}$ ): $125 \mathrm{NaCl}$, $25 \mathrm{NaHCO}_{3}, 25$ dextrose, $2.5 \mathrm{KCl}, 1.25 \mathrm{NaH}_{2} \mathrm{PO}_{4}, 1 \mathrm{MgCl}_{2}$, and $2 \mathrm{CaCl}_{2}$, $\mathrm{pH}$ 7.5. The brain was quickly removed and cooled in ice-cold oxygenated ACSF. By use of a vibroslicer, 300- $\mu$ m-thick transverse hippocampal slices were cut into a bath of ice-cold oxygenated ACSF. Slices were transferred to a holding chamber where they remained submerged in oxygenated ACSF at $35^{\circ} \mathrm{C}$ for $30 \mathrm{~min}$. The slices then remained in oxygenated ACSF at room temperature $\left(\sim 24^{\circ} \mathrm{C}\right)$ until used for recording.

Whole-cell voltage-clamp recording. Slices were transferred to a recording chamber mounted on a Zeiss Axioskop (Oberkochen, Germany) where they were submerged in oxygenated ACSF maintained at $35 \pm$ $1^{\circ} \mathrm{C}$. Neurons in the slice were visualized using infrared differential interference videomicroscopy (Hamamatsu, Hamamatsu City, Japan). Somatic whole-cell voltage-clamp recordings were obtained from CA1 pyramidal neurons using patch electrodes made from thick-walled borosilicate glass (Garner Glass, Claremont, CA) pulled on a P-97 micropipette puller (Sutter Instrument Company, Novato, CA) with an open tip resistance of 3-5 M $\Omega$ in ACSF. Series resistance (average, $12 \pm 4.1 \mathrm{M} \Omega$ ) was compensated $(70 \%)$, and a recording was terminated if a significant increase occurred. Data were collected with an Axopatch 200B amplifier (Axon Instruments, Foster City, CA) and acquired and analyzed using Igor Pro software (WaveMetrics, Inc., Lake Oswego, OR).

Synaptically evoked IPSCs and miniature IPSCs (mIPSCs) were recorded using a pipette solution containing (in mM): $140 \mathrm{CsCl}, 2 \mathrm{MgCl}_{2}$, 10 HEPES, 2 EGTA, $2 \mathrm{MgATP}, 0.3 \mathrm{NaGTP}$, and $10 \mathrm{Na}_{2}$-creatinine phosphate, with $0.10 \%$ biocytin, $\mathrm{pH}$ 7.2-7.3. Synaptically evoked IPSCs were recorded in ACSF containing $5 \mu \mathrm{M}$ kynurenic acid to block glutamate receptor-mediated synaptic transmission. A stimulating electrode (patch pipette with chlorided silver wire) was placed in the CA1 pyramidal cell layer 50-100 $\mu \mathrm{m}$ away from the recording electrode. Stimulusresponse curves were generated at a holding potential of $-70 \mathrm{mV}$ by varying stimulus intensity from the minimum current necessary to evoke a postsynaptic response to the current that produced a maximal response; stimuli were delivered at $0.1 \mathrm{~Hz}$. Synaptically evoked IPSCs were all blocked by the $\mathrm{GABA}_{\mathrm{A}}$ antagonists $10 \mu \mathrm{M}$ bicuculline or $2 \mu \mathrm{M}$ SR-95531 (SR). The stimulus-response protocol was repeated at least three times per cell, and the average of peak IPSC amplitude at each stimulus intensity was calculated for each cell. IPSC rise and decay kinetics was obtained from maximal currents, and data were averaged per cell. Stimulus-response curves were analyzed statistically with repeated measures ANOVA. IPSC rise time and time to $50 \%$ decay for cells from $\mathrm{O}$ and E animals were analyzed statistically with Student's $t$ test.

Miniature IPSCs were recorded from the same cells as synaptically evoked IPSCs after addition of $5 \mu \mathrm{M}$ TTX to the bath. Data were collected from the first 565 mIPSCs per cell. Like synaptically evoked IPSCs, mIPSCs were blocked by $10 \mu \mathrm{M}$ bicuculline or $2 \mu \mathrm{M}$ SR. The frequency of mIPSCs and mean mIPSC amplitude and decay time were analyzed statistically using ANOVA followed by Tukey post hoc comparisons. Miniature IPSC amplitude and decay time histograms were analyzed statistically using the Kolmogorov-Smirnov test. Statistical association between mIPSC amplitude and decay time was analyzed by linear regression.

EPSCs and mixed postsynaptic currents evoked by str. radiatum stimulation were recorded using a pipette solution containing (in $\mathrm{mM}$ ): 130 Cs-gluconate, $2 \mathrm{CsCl}, 2 \mathrm{MgCl}_{2}, 20 \mathrm{HEPES}, 10 \mathrm{Na}_{2}$-creatinine phosphate, 2 EGTA, $2 \mathrm{MgATP}$, and $0.3 \mathrm{NaGTP}$, with $0.10 \%$ biocytin, $\mathrm{pH} 7.3$. Before recordings began, a cut was made between the CA3 and CA1 regions to prevent retrograde activation of CA3 pyramidal cells. A stimulating electrode was placed in the str. radiatum $150-250 \mu \mathrm{m}$ laterally from the soma of the recorded cell, midway between the pyramidal cell layer and the str. lacunosum. At least three sets of minimum-tomaximum stimulus-response curves were generated for each cell from mixed postsynaptic currents as well as from isolated AMPA- and NMDA-mediated EPSCs. AMPA-mediated currents were blocked with $30 \mu \mathrm{M}$ CNQX, and NMDA-mediated currents were blocked with $10 \mu \mathrm{M}$ APV. Means for total charge transfer were calculated at each stimulus intensity for each cell and were analyzed statistically using repeated measures ANOVA. Decay times were fit with biexponentials and also were analyzed by comparing the mean time to $50 \%$ decay of currents evoked at the stimulus intensity that produced a half-maximal postsynaptic response using Student's $t$ test. 

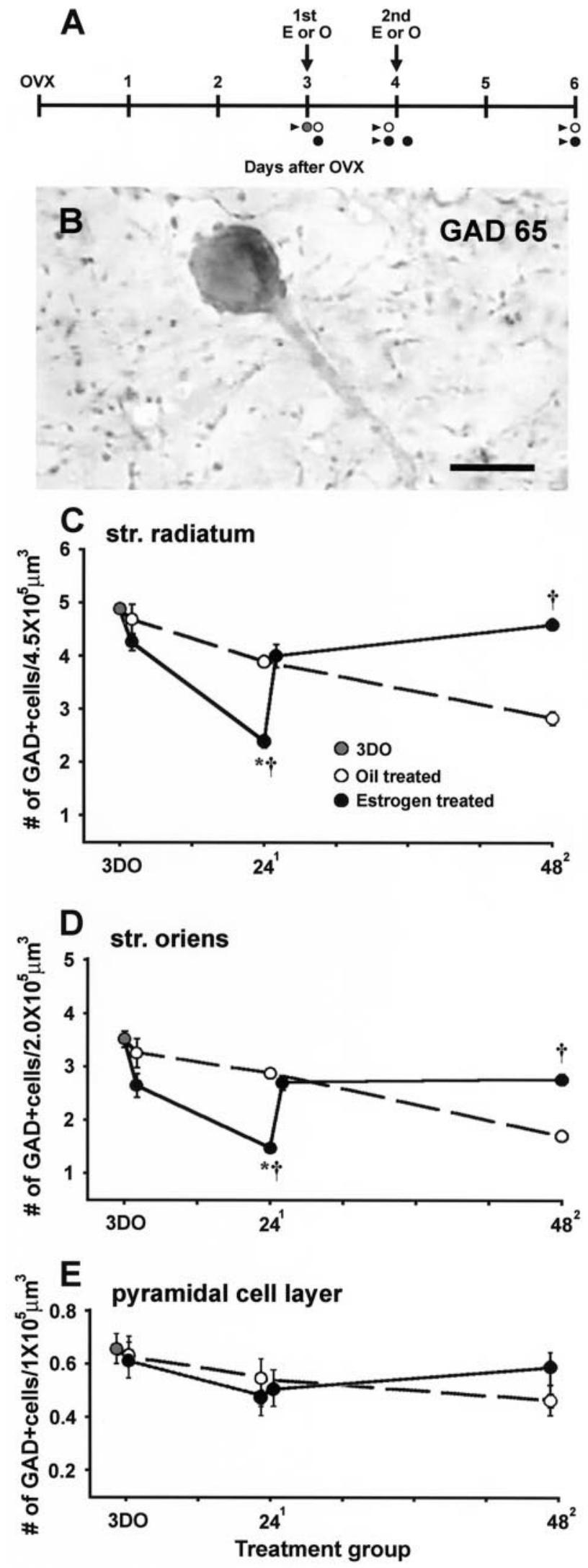

Figure 1. Estrogen regulates GAD65 immunoreactivity in CA1. A, Treatment schedule used in all studies. All rats were OVX and received $\mathrm{O}$ (white circles) or $\mathrm{E}$ (black circles) injections on the third only or third and fourth days after OVX. For immunohistochemistry, six animals were perfused at each of the following time points: $3 \mathrm{~d}$ OVX (before any

\section{RESULTS}

\section{Time course of changes in GAD65 and GAD67 immunoreactivity after estrogen}

Quantitative analysis of GAD65- and GAD67-immunoreactive cells revealed a transient estrogen-induced decrease in GAD65 immunoreactivity in both the str. radiatum and str. oriens of CA1. Similar changes were observed in the pyramidal cell layer, albeit to a much lesser extent. In control animals, the density of GAD65-labeled cells (Fig. 1B) in both dendritic layers decreased gradually from the baseline at $3 \mathrm{DO}$ to the end of the treatment period at $48^{2} \mathrm{O}$ (Fig. $1 C, D$, dashed lines $)(p<0.05)$. In estrogentreated animals, the density of GAD65-labeled cells was decreased slightly at $2^{1}$, substantially decreased by the $24^{1}$ time point (Fig. 1C,D, solid lines) $\left(p<0.05\right.$ from $3 \mathrm{DO}$ and $\left.24^{1} \mathrm{O}\right)$, but recovered at the $2^{2}$ and $48^{2}$ time points so that GAD65 labeling at $48^{2} \mathrm{E}$ was significantly greater than that at $48^{2} \mathrm{O}(p<0.05)$ and not different from that at 3DO $(p>0.1)$. Counts of GAD65immunoreactive cells in the pyramidal cell layer also showed a similar pattern of changes, but these differences represented only a statistical trend (Fig. 1E) $(p<0.1)$.

In contrast to GAD65 labeling, estrogen had no effect on the density of GAD67-labeled cells at any time point after OVX or estrogen treatment ( $p>0.1$; data not shown). Because GAD65 and GAD67 are generally coexpressed in the same neurons (Houser and Esclapez, 1994; Sloviter et al., 1996; Stone et al., 1999), the lack of effect on GAD67 suggests that GAD65 immunoreactivity is suppressed in the same cells in which GAD67 is unchanged.

Changes in GAD65 immunoreactivity could result from estrogen-induced differences in GAD65 expression and/or some other change in GAD65 that alters its antigenicity. Our subsequent analyses of synaptic currents in CA1 pyramidal cells suggest the former, i.e., changes in expression, because differences in GAD65 immunoreactivity are paralleled by differences in inhibitory synaptic function (see below). Although the reversal of GAD suppression between $24^{1} \mathrm{E}$ and $2^{2} \mathrm{E}$ is quite rapid, it is possible that even this change represents an increased GAD expression because estrogen is known to very rapidly activate neuronal protein synthetic machinery (Jones et al., 1988, 1990) and GAD expression has been shown previously to be rapidly modulated by other manipulations (Bowers et al., 1998; Szabo et al., 2000; Churchill et al. 2001).

\section{Synaptic inhibition at the $24^{1}$ time point \\ Synaptically evoked IPSCs}

Estrogen-induced differences in GAD65 immunoreactivity were paralleled by functional differences in $\mathrm{GABA}_{\mathrm{A}}$ inhibition of $\mathrm{CA} 1$

\section{$\leftarrow$}

injections; gray circle), 2 or $24 \mathrm{hr}$ after the first $\mathrm{O}$ or E injection, $48 \mathrm{hr}$ after the second $\mathrm{O}$ injection, and 2 or $48 \mathrm{hr}$ after the second $\mathrm{E}$ injection. Electrophysiological analyses were performed on a variable number of animals at the following time points (arrowheads): $3 \mathrm{DO}, 24^{1} \mathrm{O}, 24^{1} \mathrm{E}$, $48^{2} \mathrm{O}$, and $48^{2} \mathrm{E}$. $B$, Representative GAD65-immunoreactive cell in the CA1 str. radiatum. Scale bar, $10 \mu \mathrm{m}$. $C-E$, Time course of changes in the density of GAD65-immunoreactive cells in the CA1 str. radiatum $(C)$, str. oriens $(D)$, and pyramidal cell layer $(E)$ in O- and E-treated animals, compared with $3 \mathrm{DO}$ animals. In str. radiatum and str. oriens, GAD65 immunoreactivity declines gradually in O-treated controls, but in E-treated animals, GAD65 decreases sharply at $24{ }^{1} \mathrm{E}$ and then recovers by $48^{2} \mathrm{E}$. Asterisks indicate a significant difference from 3DO, and crosses indicate a significant difference from the O-treated control at the same time point $(p<0.05)$. In the pyramidal cell layer, GAD65 immunoreactivity follows a similar pattern, but differences reflect only a statistical trend $(p<0.1)$. Note that $y$-axes in $C-E$ are different. 

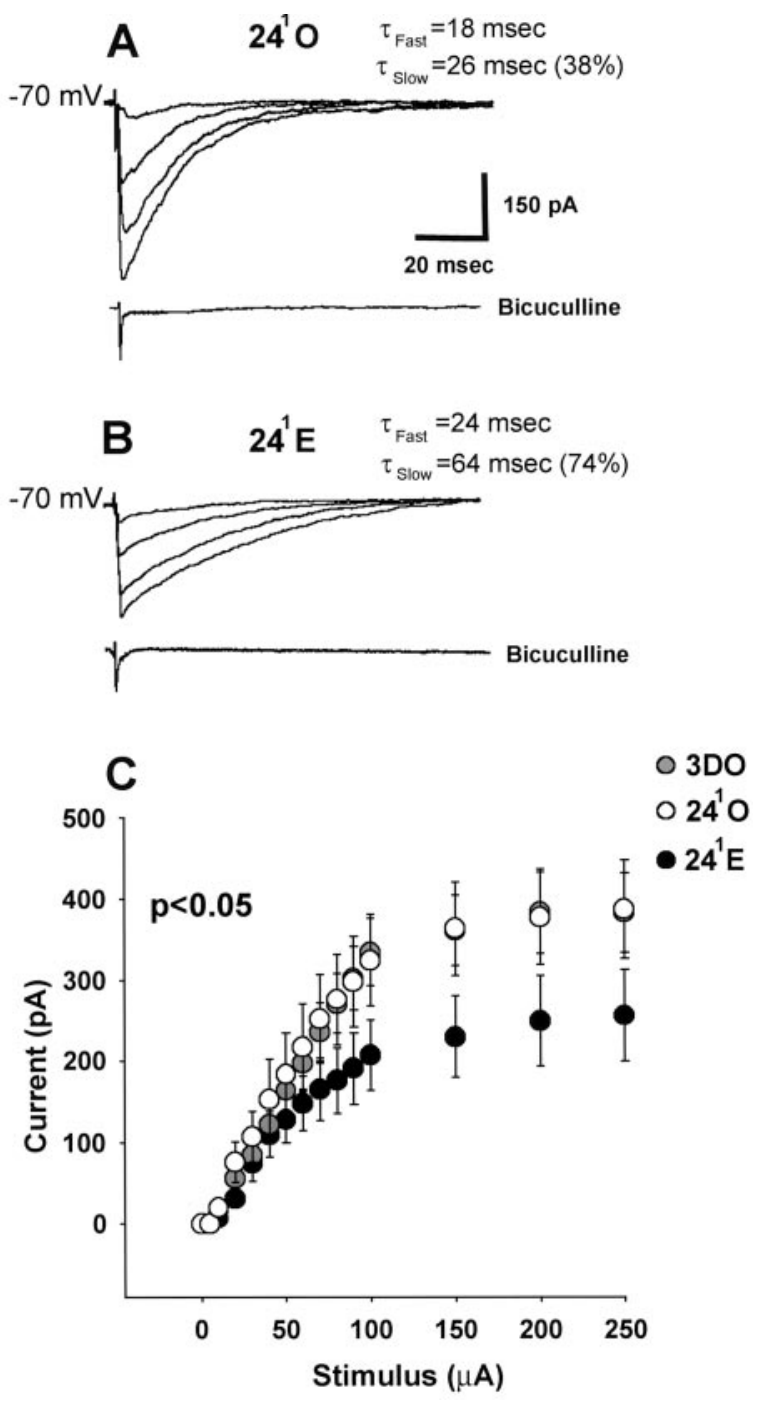

Figure 2. Estrogen reduces amplitude and increases decay time of synaptically evoked IPSCs in CA1 pyramidal cells at the $24^{1}$ time point. Recordings were made with a $\mathrm{CsCl}$ internal solution. $A$, Representative individual traces of IPSCs evoked in a $24^{1} \mathrm{O}$ cell using 50,100, 150, and $250 \mu \mathrm{A}$ stimulating currents. $B$, Representative individual traces of IPSCs evoked in a $24^{1} \mathrm{E}$ cell using the same stimulus intensities as in $A$. Evoked currents are blocked by bicuculline. $\tau_{\text {decay fast }}$ and $\tau_{\text {decay slow }}$ values in $A$ and $B$ apply specifically to the cells shown. $C$, Averaged stimulus-response curves for 3DO (gray circles; $n=12$ cells from 6 animals), $24{ }^{1} \mathrm{O}$ (white circles; $n=18$ cells from 10 animals), and $24{ }^{1} \mathrm{E}$ (black circles; $n=22$ cells from 10 animals) groups. Peak IPSC amplitudes are significantly reduced in $24{ }^{1} \mathrm{E}$ cells compared with $24^{1} \mathrm{O}$ and $3 \mathrm{DO}$ cells $(p<0.05)$.

pyramidal cells. Isolated IPSCs were recorded using a $\mathrm{CsCl}$ based internal solution so that the $\mathrm{GABA}_{\mathrm{A}}$-mediated IPSC was an inward current. Series of synaptically evoked IPSCs in cells from $3 \mathrm{DO}, 24{ }^{1} \mathrm{O}$ (Fig. $2 A$ ), and $24{ }^{1} \mathrm{E}$ (Fig. $2 B$ ) animals were used to generate stimulus-response curves (Fig. $2 C$ ). Comparison of these stimulus-response curves showed that evoked IPSC amplitude was significantly reduced in cells from $24{ }^{1} \mathrm{E}$ animals compared with those from $24^{1} \mathrm{O}$ and 3DO animals $(p<0.05)$.

In addition to decreasing evoked IPSC amplitude, estrogen also prolonged the decay of evoked IPSCs at the $24^{1}$ time point (Fig. $2 A$ vs $B$ ). Synaptically evoked IPSCs were best described by two time constants, $\tau_{\text {decay fast }}$ and $\tau_{\text {decay slow }}$ (Pearce, 1993), each of which was greater in the $24{ }^{1} \mathrm{E}$ than in the $24{ }^{1} \mathrm{O}$ or $3 \mathrm{DO}$ groups
(Table $\left.1 ; \tau_{\text {decay fast }}, p<0.05 ; \tau_{\text {decay slow }}, p<0.01\right)$. Additionally, at $24{ }^{1} \mathrm{E}, \tau_{\text {decay slow }}$ accounted for an average of $71 \pm 4.5 \%$ of the synaptic current compared with only $38 \pm 2.9 \%$ at $24{ }^{1} \mathrm{O}$ (Table 1 ; $p<0.01)$. We also analyzed IPSC decay kinetics on the basis of time to $50 \%$ decay, which was significantly greater in $24{ }^{1} \mathrm{E}$ compared with $24{ }^{1} \mathrm{O}$ cells (Table $1 ; p<0.01$ ). In contrast to decay times, rise times of synaptically evoked IPSCs were unchanged at the $24^{1}$ time point (Table $1 ; p>0.1$ ).

There are at least two possible sources of the estrogen-induced increase in decay time of synaptically evoked IPSCs. First, prolonged IPSC decay could be caused by estrogen-induced changes in the subunit composition of postsynaptic $\mathrm{GABA}_{\mathrm{A}}$ receptors (Smith et al., 1998). Second, estrogen could alter the relative contribution to the IPSC of somatic versus dendritic $\mathrm{GABA}_{\mathrm{A}}$ synapses, which have been shown to produce synaptic currents with varying decay times. Pearce (1993) demonstrated two anatomically and functionally distinct subpopulations of $\mathrm{GABA}_{\mathrm{A}}$ synapses on CA1 pyramidal cells: somatic GABA inputs that produce synaptic currents with predominantly fast rise and decay times and dendritic GABA inputs that produce slowly rising and decaying synaptic currents. If estrogen alters the balance of somatic versus dendritic GABA input in favor of dendritic inputs, this might account for the prolongation of synaptically evoked IPSCs at $24{ }^{1} \mathrm{E}$. However, two observations make this explanation insufficient to account for the prolonged IPSC decay that we observed. First, we detected no difference in IPSC rise times between $24{ }^{1} \mathrm{O}$ and $24{ }^{1} \mathrm{E}$ cells, which is inconsistent with the slow $\mathrm{GABA}_{\mathrm{A}}$ currents described by Pearce. Second, slow GABA currents arise primarily from distal dendritic inputs and so are not likely to contribute substantially to postsynaptic currents evoked by stimulation in the pyramidal cell layer. Together, these observations favor an alteration in postsynaptic $\mathrm{GABA}_{\mathrm{A}}$ receptor subunit composition as a source of prolonged $\mathrm{GABA}_{\mathrm{A}}$ IPSCs at $24{ }^{1} \mathrm{E}$.

\section{Miniature IPSCs}

To determine whether the reduced amplitude of synaptically evoked IPSCs in $24{ }^{1} \mathrm{E}$ cells was paralleled by a decrease in either the frequency and/or amplitude of individual synaptic events, we recorded $\mathrm{GABA}_{\mathrm{A}}$-mediated mIPSCs in TTX. Analysis of mIPSCs in $3 \mathrm{DO}, 24{ }^{1} \mathrm{O}$ (Fig. $3 A$ ), and $24{ }^{1} \mathrm{E}$ (Fig. $3 B$ ) cells showed a significant decrease in mIPSC frequency in $24{ }^{1} \mathrm{E}$ cells compared with those in both $3 \mathrm{DO}$ and $24^{1} \mathrm{O}$ cells (Fig. $3 C$, Table 1; $p<0.05)$. In contrast to mIPSC frequency, the mean amplitude of mIPSCs was not significantly affected by estrogen treatment, although there was a trend toward larger currents in the $24{ }^{1} \mathrm{E}$ cells (Fig. 4, Table 1; $p<0.1$ ). Comparison of mIPSC amplitude histograms for $3 \mathrm{DO}$ (Fig. $4 A$ ), $24{ }^{1} \mathrm{O}$ (Fig. $4 B$ ), and $24{ }^{1} \mathrm{E}$ (Fig. $4 C$ ) cells showed that the distribution was skewed toward larger currents in the $24{ }^{1} \mathrm{E}$ group (Fig. $\left.4 D\right)(p<0.01)$, accounting for the statistical trend toward greater mean mIPSC amplitude at $24^{1} \mathrm{E}$. Together, these results indicate that the reduction in amplitude of synaptically evoked IPSCs at $24{ }^{1} \mathrm{E}$ is not caused by a decrease in the amplitude of individual $\mathrm{GABA}_{\mathrm{A}}$-mediated synaptic currents but may result from a decrease in the number of functional $\mathrm{GABA}_{\mathrm{A}}$ synapses or the probability of GABA release.

In agreement with the prolonged decay of synaptically evoked IPSCs in $24{ }^{1} \mathrm{E}$ cells, a subpopulation of mIPSCs in the same cells also showed prolonged decay times compared with 3DO (Fig. 5A) and $24{ }^{1} \mathrm{O}$ (Fig. $5 B$ ) cells. Similar to the data for mIPSC amplitude, there was a statistical trend toward increased mean mIPSC decay time at $24{ }^{1} \mathrm{E}$ (Table $1 ; p<0.1$ ), which reflected a bimodal distribution of mIPSC decay times for this group (Fig. 5C). A 


\begin{tabular}{|c|c|c|c|c|c|}
\hline & \multicolumn{5}{|c|}{ Treatment group } \\
\hline & $3 \mathrm{DO}$ & $24^{1} \mathrm{O}$ & $24^{1} \mathrm{E}$ & $48^{2} \mathrm{O}$ & $48^{2} \mathrm{E}$ \\
\hline \multicolumn{6}{|l|}{ Evoked IPSCs } \\
\hline$\tau_{\text {rise }}(\mathrm{msec})$ & $0.9 \pm 0.1$ & $1.0 \pm 0.1$ & $1.0 \pm 0.1$ & $0.9 \pm 0.1$ & $1.0 \pm 0.1$ \\
\hline$\tau_{\text {decay fast }}(\mathrm{msec})$ & $11.3 \pm 3.2$ & $11.9 \pm 2.9$ & $16.1 \pm 2.4^{* \dagger}$ & $12.7 \pm 3.1$ & $10.9 \pm 4.2$ \\
\hline$\tau_{\text {decay slow }}(\mathrm{msec})$ & $31.5 \pm 6.1$ & $30.9 \pm 5.2$ & $43.8 \pm 5.6^{* * \dagger \dagger}$ & $32.7 \pm 6.7$ & $29.3 \pm 5.9$ \\
\hline$\tau_{\text {slow }}$ relative amplitude $(\%)$ & $40 \pm 3.1$ & $38 \pm 2.9$ & $71 \pm 4.5^{* * \dagger \dagger}$ & $42 \pm 3.3$ & $39 \pm 2.8$ \\
\hline Time to $50 \%$ decay (msec) & $14.7 \pm 1.9$ & $13.1 \pm 1.6$ & $22.1 \pm 2.1^{* * \dagger \dagger}$ & $12.6 \pm 1.3$ & $11.2 \pm 1.1$ \\
\hline Max amplitude (pA) & $383.2 \pm 49.5$ & $390.8 \pm 49.9$ & $242.8 \pm 48.1^{* \dagger}$ & $175.0 \pm 20.3$ & $391.7 \pm 43.1^{\dagger \dagger}$ \\
\hline \multicolumn{6}{|l|}{ Miniature IPSCs } \\
\hline Frequency (Hz) & $12.5 \pm 0.4$ & $11.6 \pm 0.8$ & $8.4 \pm 0.7^{* \dagger}$ & $7.1 \pm 0.9$ & $15.5 \pm 0.8^{\dagger \dagger}$ \\
\hline$\tau_{\text {rise }}(\mathrm{msec})$ & $0.69 \pm 0.1$ & $0.59 \pm 0.1$ & $0.64 \pm 0.1$ & $0.60 \pm 0.1$ & $0.56 \pm 0.1$ \\
\hline Decay time (msec) & $7.4 \pm 1.1$ & $7.2 \pm 1.0$ & $9.8 \pm 1.6$ & $7.4 \pm 2.1$ & $7.4 \pm 1.1$ \\
\hline Amplitude (pA) & $14.5 \pm 2.9$ & $14.1 \pm 2.7$ & $19.6 \pm 4.1$ & $17.4 \pm 3.4$ & $15.3 \pm 2.9$ \\
\hline
\end{tabular}

Data are means \pm SEM. Units are indicated in parentheses.

*indicates a significant difference from 3DO $(p<0.05)$.

$* *$ indicates a significant difference from 3DO $(p<0.01)$.

†indicates a significant difference from the oil-treated control at the corresponding time point $(p<0.05)$.

$\dagger$ indicates a significant difference from the oil-treated control at the corresponding time point $(p<0.01)$.

significant proportion of mIPSCs in the $24^{1} \mathrm{E}$ group was prolonged compared with mIPSCs in $3 \mathrm{DO}$ or $24^{1} \mathrm{O}$ (Fig. $\left.5 D\right)(p<$ $0.01)$; clearly bimodal decay time histograms were observed for 20 of 22 cells at $24^{1} \mathrm{E}$. In contrast to decay time, mIPSC rise time was not affected by estrogen (Table $1 ; p>0.1$ ). Interestingly, regression analysis of the first $50 \mathrm{mIPSC}$ per cell showed a weak but statistically significant correlation between mIPSC amplitude and decay time $(r=0.33 ; p<0.01$; data not shown). Thus, the larger-amplitude mIPSCs were a subset of the mIPSCs with prolonged decay times.

Analysis of mIPSCs corroborated the interpretation that prolonged IPSC decay was caused by something other than an enhancement of the slow dendritic $\mathrm{GABA}_{\mathrm{A}}$ inputs described by Pearce (1993). Because mIPSCs with prolonged decay were frequent in our somatic recordings and distal dendritic inputs should be only infrequently represented in somatic recordings, it is unlikely that these inputs underlie the mIPSCs with prolonged decay. In addition, as with evoked IPSCs, mIPSC rise time was not affected by estrogen. Thus, these data point toward changes in postsynaptic $\mathrm{GABA}_{\mathrm{A}}$ receptor subunit composition as a more likely explanation for prolonged IPSC decay. Also, because we observed a distinct subpopulation of mIPSCs with prolonged decay times rather than a uniform increase in mIPSC decay time, this indicates that the GABA synapses altered at $24{ }^{1} \mathrm{E}$ are a subset of all GABA synapses detectable in somatic recordings.

\section{Postsynaptic currents evoked by str. radiatum stimulation}

IPSCs evoked by pyramidal cell layer stimulation and mIPSCs primarily reflect somatic and proximal dendritic GABA inputs, whereas we observed the greatest effects of estrogen on GAD65 immunoreactivity in the str. radiatum and str. oriens, which contain GABA neurons that provide primarily dendritic inputs. To investigate how estrogen affects the interaction between EP-

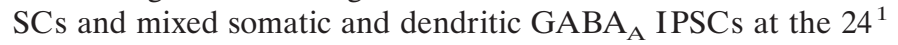
time point, we recorded postsynaptic currents elicited by stimulation of the principal excitatory pathway into the CA1 region, the Schaffer collateral axons in the str. radiatum. Recordings were made in normal ACSF followed by addition of a $\mathrm{GABA}_{\mathrm{A}}$ receptor antagonist (bicuculline or SR). Mixed currents evoked by str. radiatum stimulation were recorded at $-70 \mathrm{mV}$ holding potential with a Cs-gluconate internal solution so that glutamate receptormediated EPSCs were inward currents and the $\mathrm{GABA}_{\mathrm{A}^{-}}$ mediated IPSC was an outward current. In agreement with a reduction in disynaptic inhibition at $24^{1} \mathrm{E}$, recordings in normal ACSF showed that mixed postsynaptic currents in cells from the $24{ }^{1} \mathrm{E}$ group were prolonged compared with those in $24{ }^{1} \mathrm{O}$ cells (Fig. 6A). The mean time to $50 \%$ decay of synaptically evoked currents was $42 \%$ greater in $24{ }^{1} \mathrm{E}$ cells than in $24{ }^{1} \mathrm{O}$ cells (Fig. $6 C)(p<0.01)$. This difference in decay time was very likely caused by the difference in $\mathrm{GABA}_{\mathrm{A}}$-mediated inhibition because it was eliminated by addition of bicuculline or SR (Fig. 6B,D). Recording at a holding potential of $+40 \mathrm{mV}$ in the presence of a $\mathrm{GABA}_{\mathrm{A}}$ antagonist and CNQX showed no effect of estrogen on NMDA-mediated currents at the $24^{1}$ time point. The averaged peak amplitude of NMDA-mediated EPSCs was $56.3 \pm 7.1 \mathrm{pA}$ in the $24{ }^{1} \mathrm{E}$ group versus $57.1 \pm 5.9 \mathrm{pA}$ in the $24{ }^{1} \mathrm{O}$ group $(p>0.1$; data not shown).

\section{Synaptic inhibition at the $48^{2}$ time point}

Synaptically evoked IPSCs

Similar to experiments at the $24^{1}$ time point, the amplitude of synaptically evoked IPSCs in CA1 pyramidal cells at the $48^{2}$ time point also paralleled GAD65 immunoreactivity. Note that at this later time point, GAD65 staining is greater in $48^{2} \mathrm{E}$ than in $48^{2} \mathrm{O}$ animals (Fig. $1 C-E$ ). As with experiments at the $24^{1}$ time point, isolated IPSCs were recorded using a CsCl-based internal solution so that the $\mathrm{GABA}_{\mathrm{A}}$-mediated IPSC was an inward current. Analysis of stimulus-response curves for synaptically evoked IPSCs in $3 \mathrm{DO}, 48^{2} \mathrm{O}$ (Fig. $7 A$ ), and $48^{2} \mathrm{E}$ (Fig. $7 B$ ) cells showed that peak IPSC amplitude was greater in cells from $48^{2} \mathrm{E}$ than from $48^{2} \mathrm{O}$ animals (Fig. $\left.7 C\right)(p<0.01)$. The reversal of the $\mathrm{O}$ versus E relationship at $48^{2}$ compared with $24^{1}$ is caused partly by the decrease in IPSC amplitude in $48^{2} \mathrm{O}$ cells and partly by the recovery of IPSC amplitude in $48^{2} \mathrm{E}$ cells. In cells from $48^{2} \mathrm{E}$ animals, evoked IPSC amplitudes had recovered to values that were no longer different from that in 3DO cells (Fig. 7C) $(p>0.1)$.

In contrast to $24^{1}$, the decay kinetics of evoked IPSCs at the $48^{2}$ time point was not different between $3 \mathrm{DO}, 48^{2} \mathrm{O}$, and $48^{2} \mathrm{E}$. 

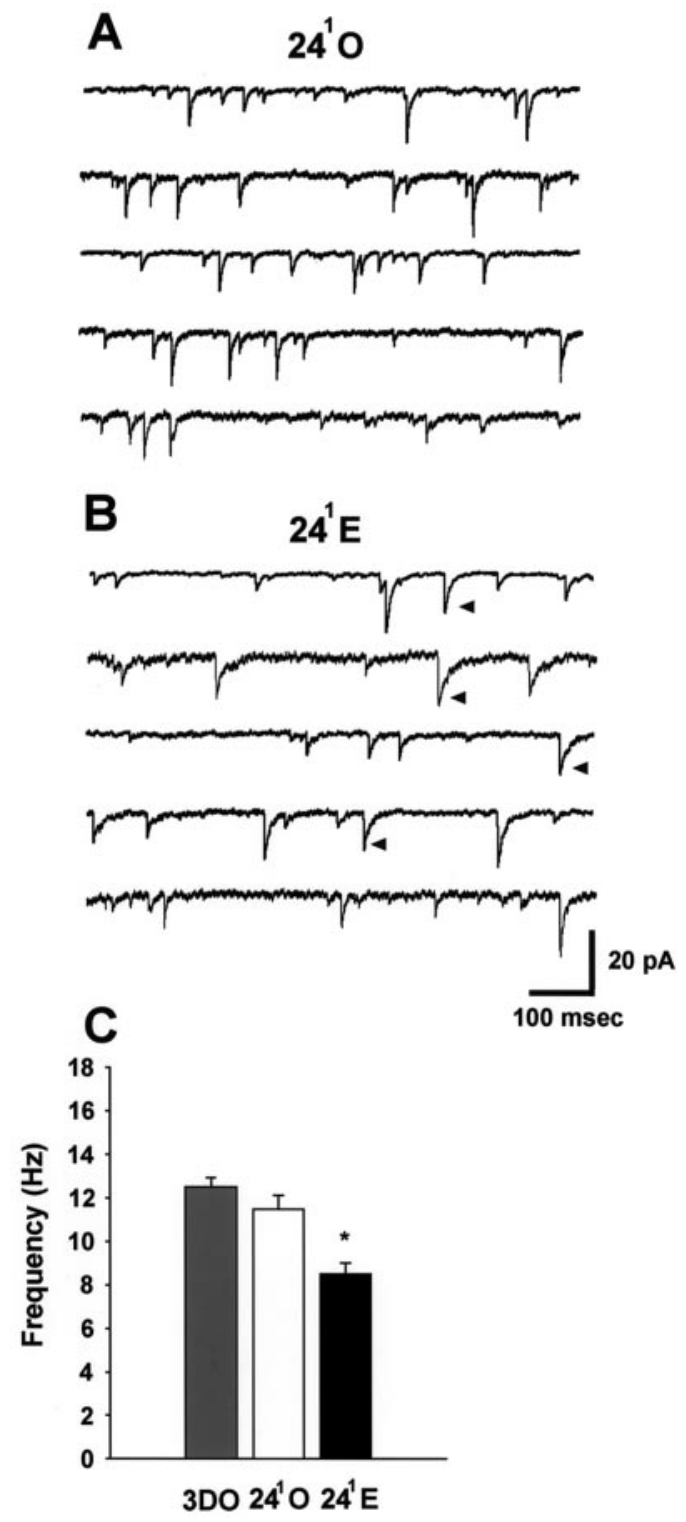

Figure 3. Estrogen reduces the frequency of mIPSCs in CA1 pyramidal cells at the $24^{1}$ time point. $A$, Representative traces from five different $24^{1} \mathrm{O}$ cells showing mIPSCs. $B$, Representative traces from five different $24{ }^{1} \mathrm{E}$ cells showing mIPSCs. Arrowheads indicate representative mIPSCs with a prolonged decay time in $24^{1} \mathrm{E}$ cells. $C$, Bar graph of mIPSC frequency in 3DO ( gray bar; $n=12$ cells from 6 animals), $24^{1} \mathrm{O}$ (white bar; $n=18$ cells from 10 animals), and $24{ }^{1} \mathrm{E}$ (black bar; $n=22$ cells from 10 animals) groups. Data are from the same cells shown in Figure $2 C$. The asterisk indicates a significant difference from $3 \mathrm{DO}$ and $24{ }^{1} \mathrm{O}(p<0.05)$.

There were no differences detected in $\tau_{\text {decay fast, }} \tau_{\text {decay slow }}$, or time to $50 \%$ decay of evoked IPSCs (Table $1 ; p>0.1$ ). Thus, the prolonged decay time of synaptically evoked IPSCs seen in $24{ }^{1} \mathrm{E}$ cells was no longer evident at the $48^{2} \mathrm{E}$ time point. Like the data at $24^{1}$, there were also no differences in rise times of synaptically evoked IPSCs at $48^{2}$ (Table $1 ; p>0.1$ ).

\section{Miniature IPSCs}

Consistent with the pattern established at the $24{ }^{1}$ time point, the frequency of mIPSCs at the $48^{2}$ time point paralleled GAD65 staining and the amplitude of synaptically evoked IPSCs. Analysis of mIPSCs in $3 \mathrm{DO}, 48^{2} \mathrm{O}$ (Fig. $8 A$ ), and $48^{2} \mathrm{E}$ (Fig. $8 \mathrm{~B}$ ) cells showed that mIPSC frequency in cells from the $48^{2} \mathrm{E}$ group had
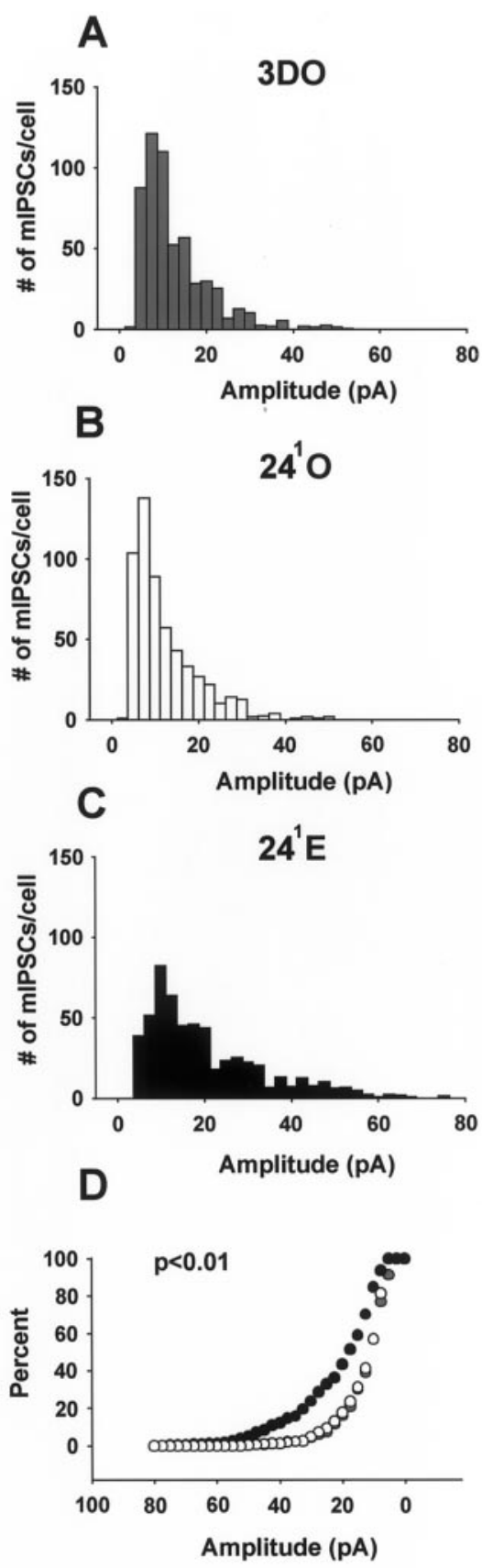

Figure 4. Estrogen alters mIPSC amplitude distributions at the $24^{1}$ time point. $A-C$, mIPSC amplitude histograms for the 3DO $(A), 24^{1} \mathrm{O}(B)$, and $24^{1} \mathrm{E}(C)$ groups. Note the shift toward larger-amplitude mIPSCs in the $24^{1} \mathrm{E}$ group. $D$, Cumulative histogram of mIPSC amplitudes for the 3DO ( gray circles), $24^{1} \mathrm{O}$ (white circles), and $24^{1} \mathrm{E}$ (black circles) groups. Note the leftward shift in mIPSC amplitude in the $24^{1} \mathrm{E}$ group $(p<0.01)$. Data are from the same cells shown in Figure 3. Mean mIPSC amplitudes are not significantly different and are shown in Table 1.

recovered to values that were no longer different from those of the baseline 3DO group (Fig. $8 C$, Table $1 ; p>0.1$ ) but were significantly higher than those in the $48^{2} \mathrm{O}$ group (Fig. $8 C$, Table $1 ; p<$ $0.01)$. In contrast to results of mIPSC analysis at the $24^{1}$ time point, we detected no evidence of a difference in mIPSC amplitude or kinetics (means or histograms) between $3 \mathrm{DO}, 48^{2} \mathrm{O}$, and $48^{2} \mathrm{E}$ (Table $1 ; p>0.1$ ). Thus the subpopulations of larger and prolonged mIPSCs seen in $24{ }^{1} \mathrm{E}$ cells were no longer apparent at the $48^{2} \mathrm{E}$ time point. 

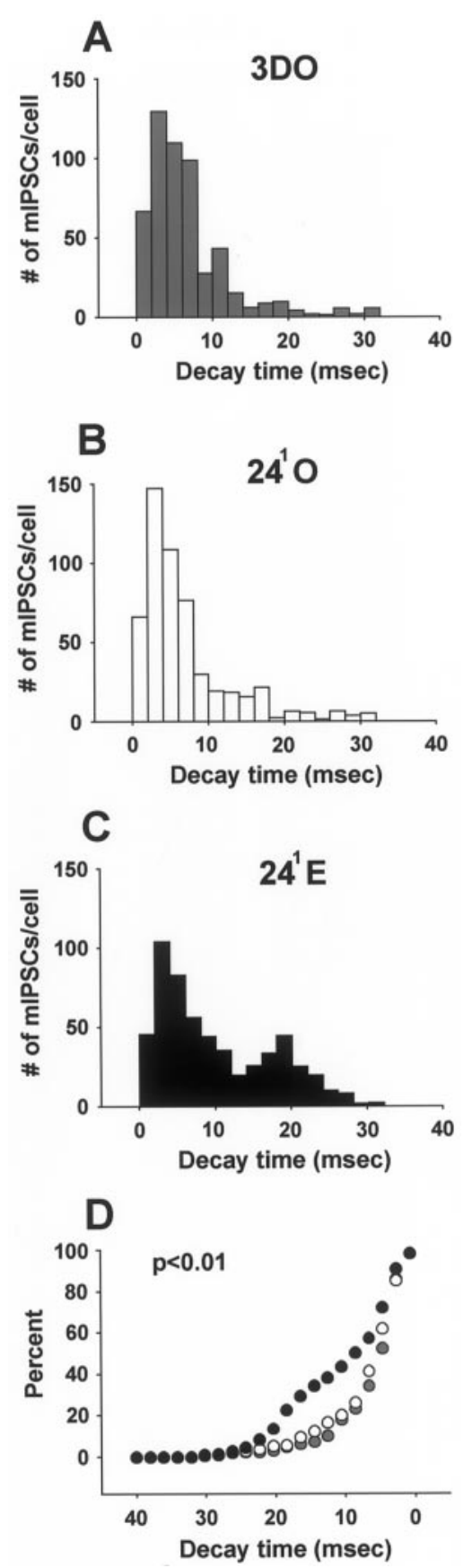

Figure 5. Estrogen alters mIPSC decay time distributions at the $24^{1}$ time point. $A-C$, mIPSC decay time histograms for the 3 DO $(A), 24^{1} \mathrm{O}(B)$, and $24{ }^{1} \mathrm{E}(C)$ groups. Note the subpopulation of mIPSCs with longer decay times in the $24^{1} \mathrm{E}$ group. $D$, Cumulative histogram of mIPSC decay times for the 3DO (gray circles), $24^{1} \mathrm{O}$ (white circles), and $24{ }^{1} \mathrm{E}$ (black circles) groups. Note the leftward shift in mIPSC decay time in the $24{ }^{1} \mathrm{E}$ group $(p<0.01)$. Data are from the same cells shown in Figures 3 and 4. Mean mIPSC decay times are not significantly different and are shown in Table 1.

\section{Postsynaptic currents evoked by st. radiatum stimulation}

Similar to our analysis of the $24^{1}$ time point, we also used str. radiatum stimulation to investigate the interaction between $\mathrm{GABA}_{\mathrm{A}}$-mediated IPSCs and glutamate receptor-mediated EPSCs at the $48^{2}$ time point. These recordings were made using a Cs-gluconate internal solution. In this case, mixed synaptic currents evoked at a holding potential of $-70 \mathrm{mV}$ in normal
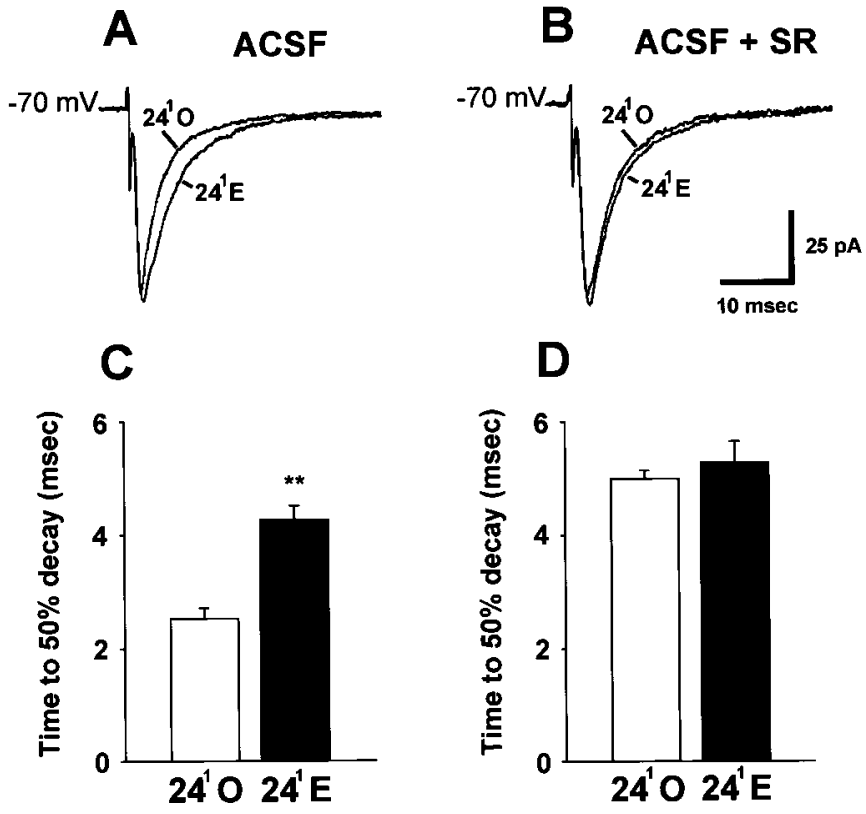

Figure 6. Reduced inhibition of CA1 pyramidal cells at the $24{ }^{1} \mathrm{E}$ time point prolongs postsynaptic currents evoked by str. radiatum stimulation. Recordings were made with a Cs-gluconate internal solution. $A$, Representative individual traces of str. radiatum-evoked postsynaptic currents in a $24{ }^{1} \mathrm{O}$ and a $24{ }^{1} \mathrm{E}$ cell in normal ACSF. B, Representative individual traces of str. radiatum-evoked postsynaptic currents in the same $24^{1} \mathrm{O}$ and $24^{1} \mathrm{E}$ cells after addition of SR-95531 to the bath. $C$, Bar graph of averaged decay times in normal ACSF for $24^{1} \mathrm{O}$ (white bar; $n=12$ cells from 6 animals) and $24^{1} \mathrm{E}$ (black bar; $n=12$ cells from 6 animals) groups. The double asterisks indicate a significant difference from $24^{1} \mathrm{O}(p<$ $0.01)$. $D$, Bar graph of averaged decay times in ACSF plus a GABA antagonist (bicuculline or SR-95531) for the same $24{ }^{1} \mathrm{O}$ and $24{ }^{1} \mathrm{E}$ cells shown in $C$. In the presence of the $\mathrm{GABA}_{\mathrm{A}}$ blocker, decay times are not different for the $24{ }^{1} \mathrm{O}$ and $24{ }^{1} \mathrm{E}$ groups.

ACSF were not different in amplitude or time course between CA1 pyramidal cells in $48^{2} \mathrm{O}$ and $48^{2} \mathrm{E}$ groups (Fig. $9 A$ ). Addition of a $\mathrm{GABA}_{\mathrm{A}}$ antagonist (SR) revealed a small, but statistically significant, difference in the time to $50 \%$ decay of the EPSC (Fig. $9 B)\left(48^{2} \mathrm{E}, 6 \%\right.$ greater than that of $\left.48^{2} \mathrm{O} ; p<0.05\right)$. We used subtraction of postsynaptic currents recorded in the presence of SR from currents recorded in normal ACSF to reveal the $\mathrm{GABA}_{\mathrm{A}}$-mediated component of total postsynaptic current elicited by str. radiatum stimulation (Fig. 9B, inset). In agreement with larger evoked IPSCs in cells from $48^{2} \mathrm{E}$ animals, the amplitude of SR-sensitive current was $36 \%$ greater in the $48^{2} \mathrm{E}$ than in the $48^{2} \mathrm{O}$ group (Fig. 9C) $(p<0.05)$. Interestingly, addition of APV eliminated the small difference in time to $50 \%$ decay of EPSCs at $-70 \mathrm{mV}$ (Fig. 9D), suggesting that estrogen enhancement of the NMDA-mediated component of the EPSC might account for the difference in EPSC decay time.

This observation suggested that the effect of the enhanced $\mathrm{GABA}_{\mathrm{A}}$-mediated IPSC on the total postsynaptic current (EPSC + IPSC) evoked by str. radiatum stimulation in $48^{2} \mathrm{E}$ cells might be masked by concurrent enhancement of NMDA EPSCs. A previous analysis based on current-clamp recording with sharp electrodes (Woolley et al., 1997) showed a steeper stimulusresponse relationship in $48^{2} \mathrm{E}$ than in $48^{2} \mathrm{O}$ cells when initial slopes of NMDA-mediated EPSPs were plotted versus stimulus intensity. AMPA-mediated EPSPs were not directly evaluated in this previous study, but baseline synaptic responses were unaffected by estrogen. These results suggested that the sensitivity of 


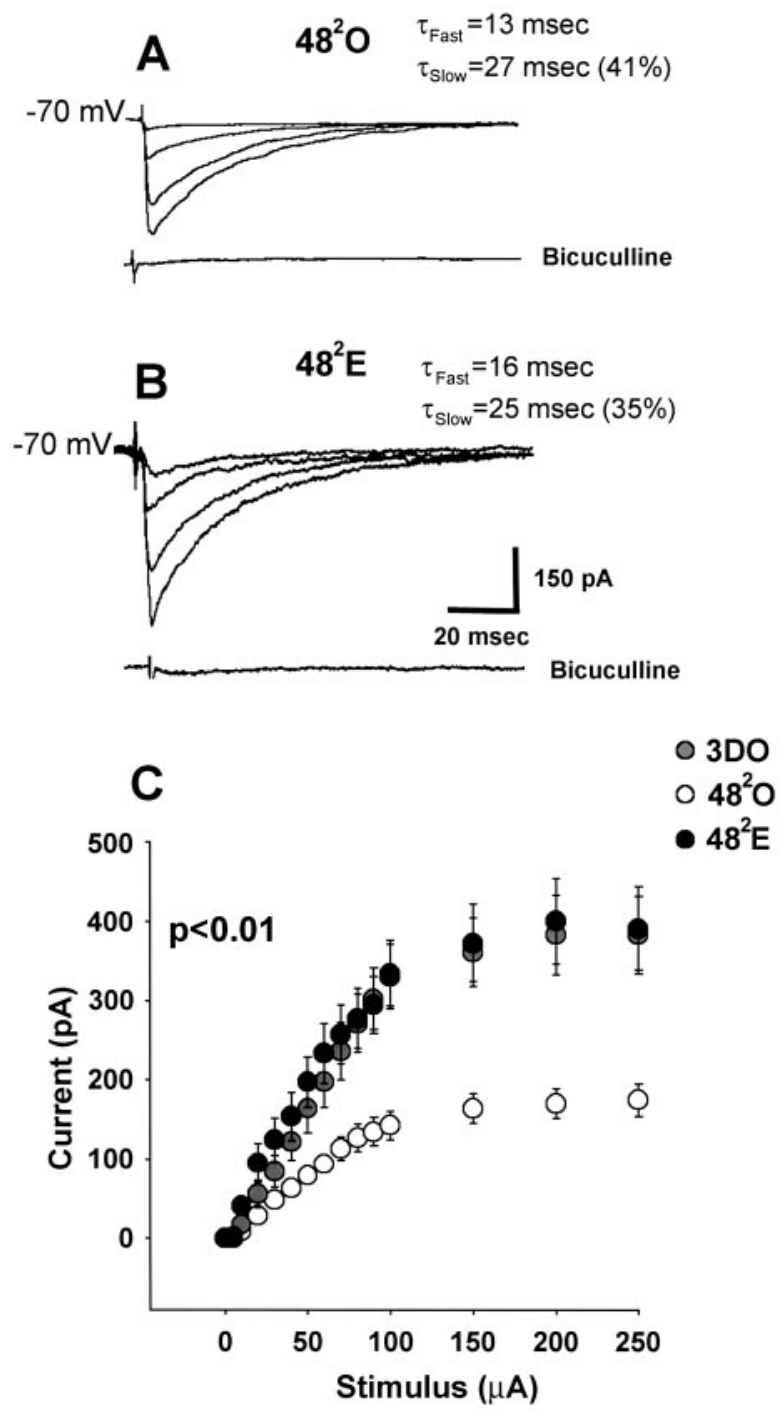

Figure 7. In estrogen-treated animals at the $48^{2}$ time point, synaptically evoked IPSC amplitude has recovered to baseline values and is greater than that in oil-treated controls. Recordings were made with a $\mathrm{CsCl}$ internal solution. $A$, Representative individual traces of IPSCs evoked in a $48^{2} \mathrm{O}$ cell using $50,100,150$, and $250 \mu \mathrm{A}$ stimulating currents. $B$, Representative individual traces of IPSCs evoked in a $48^{2} \mathrm{E}$ cell using the same stimulus intensities as in $A$. Evoked currents are blocked by bicuculline. $\tau_{\text {decay fast }}$ and $\tau_{\text {decay slow }}$ values in $A$ and $B$ apply specifically to the cells shown. $C$, Averaged stimulus-response curves for 3DO ( gray circles; $n=12$ cells from 6 animals), $48^{2} \mathrm{O}$ (white circles; $n=20$ cells from 10 animals), and $48^{2} \mathrm{E}$ (black circles; $n=22$ cells from 10 animals) groups. There is no difference in peak IPSC amplitude between $48^{2} \mathrm{E}$ and $3 \mathrm{DO}$ groups $(p>0.1)$, whereas IPSC amplitude is significantly reduced in the $48^{2} \mathrm{O}$ group compared with both $48^{2} \mathrm{E}$ and $3 \mathrm{DO}$ groups $(p<0.01)$.

CA1 pyramidal cells to NMDA, but not non-NMDA, glutamate receptor-mediated synaptic input is enhanced by estrogen. To determine directly whether NMDA- and/or AMPA-mediated currents are enhanced by estrogen at the $48^{2}$ time point, we recorded AMPA (Fig. 10 $A$ ) and NMDA (Fig. 10C) EPSCs at a holding potential of $+40 \mathrm{mV}$ to relieve $\mathrm{Mg}^{2+}$ block of the NMDA receptor. Comparison of stimulus-response curves for isolated AMPA (Fig. 10B) and NMDA (Fig. 10D) currents showed that estrogen treatment enhanced total charge transfer of NMDA- but not AMPA-mediated EPSCs. There was no effect of estrogen on the stimulus-response relationship for AMPA-

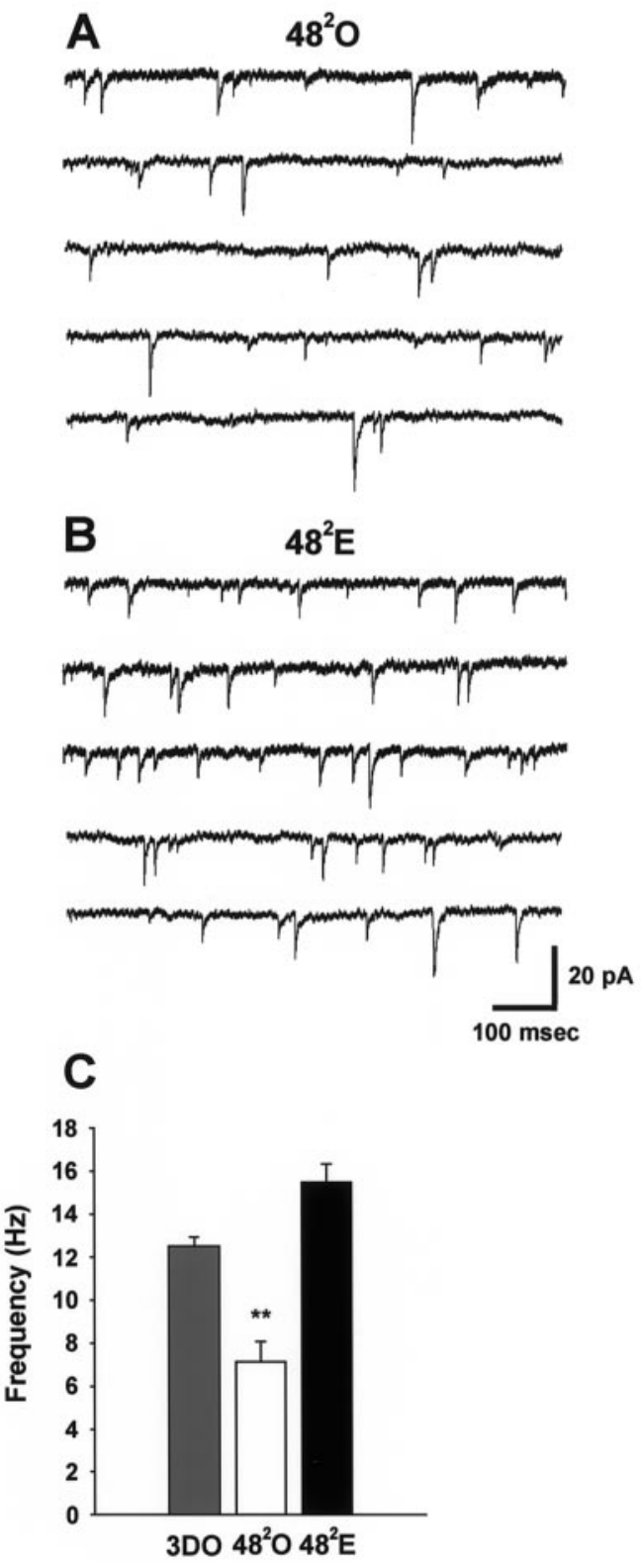

Figure 8. At the $48^{2}$ time point, the mIPSC frequency in estrogentreated animals has recovered to baseline values and is greater than that in oil-treated controls. $A$, Representative traces from five different $48^{2} \mathrm{O}$ cells showing mIPSCs. $B$, Representative traces from five different $48^{2} \mathrm{E}$ cells showing mIPSCs. $C$, Bar graph of mIPSC frequency in 3DO ( gray bar; $n=12$ cells from 6 animals), $48^{2} \mathrm{O}$ (white bar; $n=20$ cells from 10 animals), and $48^{2} \mathrm{E}$ (black bar; $n=22$ cells from 10 animals) groups. Data are from the same cells shown in Figure 7. The double asterisks indicate a significant difference from $3 \mathrm{DO}$ and $48^{2} \mathrm{E}(p<0.01)$.

mediated currents (Fig. 10B) ( $p>0.1$ ), whereas NMDA currents were significantly greater in $48^{2} \mathrm{E}$ compared with $48^{2} \mathrm{O}$ cells (Fig. $10 D)(p<0.01)$. Total charge transfer of maximal NMDAmediated EPSCs was $26 \%$ greater at $48^{2} \mathrm{E}$ than at $48^{2} \mathrm{O}$ (Fig. $10 D)(p<0.01)$. Thus, direct analysis of EPSCs confirmed the effect of estrogen to enhance the synaptic sensitivity of CA1 pyramidal cells to NMDA-mediated input (Woolley et al., 1997). The apparent lack of effect of estrogen on total synaptic currents evoked by str. radiatum stimulation at a holding potential near rest $(-70 \mathrm{mV})$ (Fig. $9 A)$ is likely caused by balanced, opposing enhancements of the NMDA EPSC and GABA IPSC. $^{2}$ 

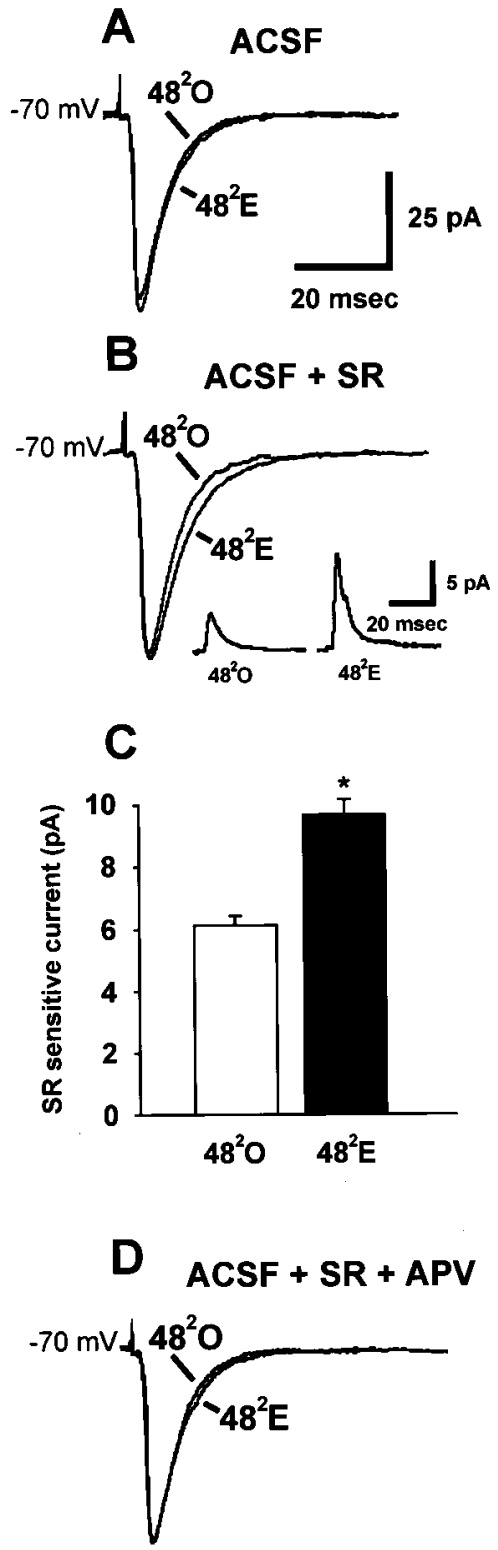

Figure 9. At the $48^{2}$ time point, $\mathrm{GABA}_{\mathrm{A}}$ receptor-mediated currents are enhanced in estrogen-treated animals, but mixed postsynaptic currents (EPSC + IPSC) are similar to those in oil-treated controls. Recordings were made with a Cs-gluconate internal solution. $A$, Representative individual traces of str. radiatum-evoked postsynaptic currents in a $48^{2} \mathrm{O}$ and a $48^{2} \mathrm{E}$ cell in normal ACSF. $B$, Representative individual traces of str. radiatum-evoked postsynaptic currents in the same $48^{2} \mathrm{O}$ and $48^{2} \mathrm{E}$ cells after addition of SR-95531. Inset, SR-sensitive (GABA $\mathrm{A}^{- \text {mediated) }}$ currents obtained by subtraction of the normal ACSF currents shown in $A$ from the ACSF + SR-95531 currents shown in B. C, Averaged amplitudes of SR-sensitive postsynaptic currents evoked by str. radiatum stimulation in the $48^{2} \mathrm{O}$ (white bar; $n=16$ cells from 8 animals) and $48^{2} \mathrm{E}$ (black bar; $n=16$ cells from 9 animals) groups. The asterisk indicates a significant difference from $48^{2} \mathrm{O}(p<0.05)$. $D$, Representative individual traces of str. radiatum-evoked postsynaptic currents in the same $48^{2} \mathrm{O}$ and $48^{2} \mathrm{E}$ cells shown in $A$ and $B$ after addition of APV and SR-95531.

\section{DISCUSSION}

We have used immunohistochemical and electrophysiological analyses to demonstrate that estrogen regulates a dynamic balance between excitatory and inhibitory synaptic input to hippocampal CA1 pyramidal cells. Ovariectomy results in a gradual decline in GAD65 immunoreactivity. Superimposed on this grad-
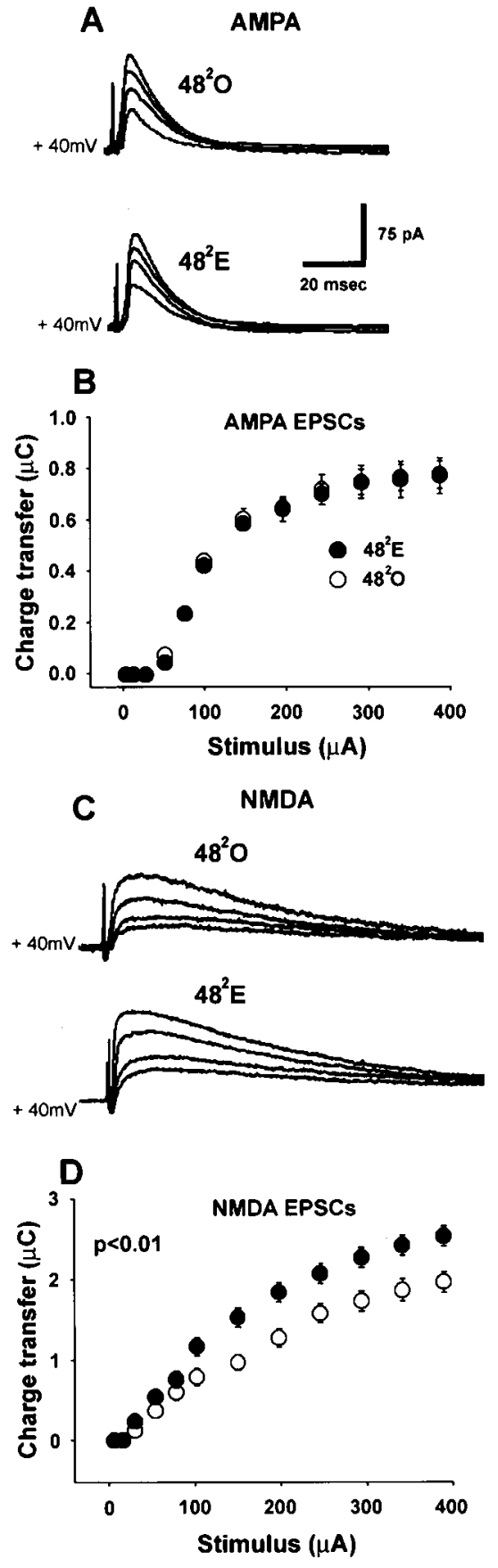

Figure 10. Estrogen enhances NMDA- but not AMPA-mediated EPSCs at the $48^{2}$ time point. $A$, Representative individual traces of str. radiatumevoked postsynaptic currents in a $48^{2} \mathrm{O}$ (upper traces) and a $48^{2} \mathrm{E}$ (lower traces) cell in ACSF containing APV + SR-95531 (AMPA-mediated EPSCs). Postsynaptic currents were evoked using 50, 150, 250 and $400 \mu \mathrm{A}$ stimulating currents. $B$, Stimulus-response curves generated from isolated AMPA receptor-mediated EPSCs for $48^{2} \mathrm{O}$ (white circles; $n=16$ cells from 9 animals) and $48^{2} \mathrm{E}$ (black circles; $n=16$ cells from 9 animals) groups. $C$, Representative individual traces of str. radiatum-evoked postsynaptic currents in the same $48^{2} \mathrm{O}$ (upper traces) and $48^{2} \mathrm{E}$ (lower traces) cells in $A$ but in ACSF containing CNQX + SR-95531 (NMDAmediated EPSCs). Postsynaptic currents were evoked using 50, 150, 250 and $400 \mu \mathrm{A}$ stimulating current. $D$, Stimulus-response curves generated from isolated NMDA receptor-mediated EPSCs for $48^{2} \mathrm{O}$ (white circles; same cells shown in $B$ ) and $48^{2} \mathrm{E}$ (black circles; same cells shown in $B$ ) groups. NMDA-mediated charge transfer is significantly greater in $48^{2} \mathrm{E}$ than in $48^{2} \mathrm{O}$ cells $(p<0.01)$. 
ual decline is a phasic effect of estrogen, in which GAD65 immunoreactivity is further suppressed $24 \mathrm{hr}$ after a single estrogen treatment $\left(24^{1}\right)$ but recovers by $48 \mathrm{hr}$ after a second estrogen treatment $\left(48^{2}\right)$.

Whole-cell voltage-clamp recordings reveal that the effects of estrogen on GAD65 are paralleled by changes in functional inhibition of CA1 pyramidal cells. Reduced inhibition at $24^{1}$ is reflected by lower-amplitude synaptically evoked IPSCs and reduced mIPSC frequency. Because mean mIPSC amplitude is not reduced by estrogen (if anything, it is increased), these data suggest that estrogen decreases the number of functional GABAergic synapses on CA1 pyramidal cells and/or decreases the probability of transmitter release at GABAergic synapses at the $24{ }^{1} \mathrm{E}$ time point. Because there is no concomitant effect of estrogen on CA1 pyramidal cell EPSCs at this time point, reduced disynaptic inhibition prolongs the total postsynaptic response to excitatory input.

In estrogen-treated animals at the $48^{2}$ time point, GAD65 immunoreactivity, synaptically evoked IPSC amplitude, and mIPSC frequency are restored to original values. Together, the recovery of inhibition in estrogen-treated animals and the gradual decrease in inhibition in ovariectomized controls result in greater inhibition in estrogen-treated than in control animals at this later time point. Additional analysis revealed that, at $48^{2}$, estrogen also enhances NMDA-mediated EPSCs in parallel with enhancement of the $\mathrm{GABA}_{\mathrm{A}}$-mediated IPSC, restoring a balance of excitatory and inhibitory input to these cells.

\section{GAD65 versus GAD67}

We found an effect of estrogen on the $65 \mathrm{kDa}$ but not the $67 \mathrm{kDa}$ isoform of GAD. The significance of this difference is difficult to predict because functional differences between the two GAD isoforms are not well understood (Erlander and Tobin, 1991; Soghomonian and Martin, 1998). Although GAD65 and GAD67 are encoded by different genes (Erlander et al., 1991), they are generally coexpressed (Houser and Esclapez, 1994; Sloviter et al., 1996; Stone et al., 1999). GAD65 tends to be concentrated in neuronal membranes, particularly in axonal varicosities, but is also expressed in the cell body (Erlander et al., 1991; Kaufman et al., 1991) of GABAergic neurons. GAD67 is more highly expressed in cell bodies than is GAD65 but is also found to a lesser extent in axons (Gonzales et al., 1991). Both GAD isoforms require a cofactor, pyridoxal-phosphate, to be active (Martin et al., 1991). Interestingly, because a large fraction of GAD that exists in the "apo" form (i.e., not bound to cofactor) is GAD65, it has been proposed that GAD65 preferentially responds to rapid changes in demand for GABA (Soghomonian and Martin, 1998). Thus estrogen effects on GAD65 may reflect differences in the capacity of CA1 interneurons for activity-dependent changes in GABA synthesis.

\section{Estrogen-sensitive interneurons}

In dorsal CA1, at least one form of the nuclear estrogen receptor $(\mathrm{ER} \alpha)$ is expressed primarily in GABAergic interneurons. The greatest concentration of $\mathrm{ER} \alpha$-immunoreactive GAD cells is found at the border between str. radiatum and str. lacunosummoleculare (Weiland et al., 1997; Hart and Woolley, 2000); however, only a small subset [ $<30 \%$ (Hart and Woolley, 2000)] of all GAD neurons in this region express $\operatorname{ER} \alpha$. Thus, although one interneuron may contact over 1000 pyramidal cells (Freund and Buzsaki, 1996), it seems unlikely that this small subpopulation of interneurons could mediate the highly consistent effects of estro- gen on inhibition via direct interneuron-pyramidal cell connections. However, some interneurons at the radiatum-lacunosum border also project to other interneurons (Kunkel et al., 1988; Lacaille and Schwartzkroin, 1988) and so are well positioned to mediate multiplicative effects of estrogen via connections with interneurons that then project to pyramidal cells. Indeed, some targets of border interneurons are interneurons in the pyramidal cell layer (Banks et al., 2000). One speculative possibility is that estrogen modulates somatic inhibition of pyramidal cells indirectly via border interneuron to pyramidal cell layer interneuron interactions.

\section{The role of disinhibition in dendritic spine formation}

There is a rich literature describing activity-dependent maintenance or formation of dendritic spines (for review, see Harris, 1999; Smart and Halpain, 2000). Two lines of reasoning support the suggestion that disinhibition of CA1 pyramidal cells at the $24{ }^{1} \mathrm{E}$ time point is involved, at least in part, in estrogen-induced dendritic spine/synapse formation. First, as would be required of a causal factor, the disinhibition at $24^{1}$ occurs before spine/ synapse changes occur (Woolley and McEwen, 1993). Second, the estrogen-induced changes in GAD immunoreactivity and functional inhibition of CA1 pyramidal cells that we observed very closely parallel the findings of Murphy et al. (1998) who demonstrated that estrogen-induced dendritic spine formation on cultured hippocampal neurons is caused by a transient reduction in GABA-mediated neurotransmission.

However, although our data are, in part, consistent with the possibility that disinhibition is involved in estrogen-induced dendritic spine formation, disinhibition alone cannot completely account for spine formation in vivo. If disinhibition were sufficient to induce new spines, spine density would be increased in ovariectomized, oil-treated animals, which showed a gradual reduction in inhibition between the $3 \mathrm{DO}$ and $48^{2} \mathrm{O}$ time points. However, previous studies have shown that spine density is low at the $48^{2} \mathrm{O}$ time point (Gould et al., 1990; Woolley and McEwen, 1993; Woolley et al., 1997), or even with longer periods of ovariectomy (Woolley and McEwen, 1993). At least two factors distinguish disinhibition of CA1 pyramidal cells observed at the $24^{1} \mathrm{E}$ versus $48^{2} \mathrm{O}$ time points; these factors may be related to different consequences of disinhibition at $24^{1} \mathrm{E}$ versus $48^{2} \mathrm{O}$ for spine formation. First, although evoked IPSC amplitude and mIPSC frequency were similarly low in $24{ }^{1} \mathrm{E}$ and $48^{2} \mathrm{O}$ animals, inhibitory currents at $24^{1} \mathrm{E}$ had several features not seen in any other group. Both synaptically evoked IPSCs and a substantial subpopulation of mI PSCs were significantly prolonged in $24{ }^{1} \mathrm{E}$ cells. In addition, mIPSC amplitudes were shifted toward larger values at $24{ }^{1} \mathrm{E}$. These features suggest that inhibition at $24{ }^{1} \mathrm{E}$ is functionally distinct from that seen at $48^{2} \mathrm{O}$. Second, the disinhibition at $24{ }^{1} \mathrm{E}$ results from a sharp decline in measures of GABAergic synaptic transmission as opposed to the gradual decline observed at $48^{2} \mathrm{O}$. The consequences of sharp versus gradual disinhibition for dendritic spine formation are currently unknown, but this difference in timing could be important in the regulation of spine density. A third factor that should be considered in the mechanism of estrogen regulation of spine density in vivo is the possibility that extrahippocampal afferents interact with disinhibition of CA1 pyramidal cells to regulate spine density. In agreement with this suggestion, Leranth et al. (2000) have shown recently that removal of subcortical input to the hippocampus via fimbria/fornix transection blocks the effect of estrogen to increase dendritic spine synapse density in CA1 in vivo. It is conceivable that the 
timing of interactions with subcortical inputs is effective at the $24^{1}$ but not the $48^{2}$ time point.

\section{Dynamic balance of excitatory and inhibitory synaptic input to CA1 pyramidal cells}

Functional analysis of $\mathrm{GABA}_{\mathrm{A}^{-}}$and NMDA-mediated synaptic input to CA1 pyramidal cells shows that both are enhanced in estrogen-treated compared with control animals at the $48^{2}$ time point. This $\left(48^{2}\right)$ is the same time point used in previous studies that demonstrated estrogen-induced increases in CA1 dendritic spine and synapse density (Gould et al., 1990; Woolley and McEwen, 1992, 1993; Woolley et al., 1997) and enhancement of excitatory synaptic input to CA1 pyramidal cells (Wong and Moss, 1992; Woolley et al., 1997). Previous studies suggested that synaptic sensitivity to NMDA-mediated input was increased in parallel with dendritic spine/synapse numbers (Woolley et al., 1997). Here, direct analysis of NMDA and AMPA EPSCs at $48^{2}$ confirmed that NMDA currents are increased by estrogen, leading to a balance in enhancement of NMDA-mediated excitatory input and $\mathrm{GABA}_{\mathrm{A}}$-mediated inhibitory input to CA1 pyramidal cells. Although this balance results in little net effect of estrogen on normal synaptic transmission, it might also be expected to increase the dynamic range of the responses of CA1 pyramidal cells to synaptic input. Enhancement of NMDA currents may underlie estrogen facilitation of long-term potentiation in CA1 (Cordoba-Montoya and Carrer, 1997) and hippocampusdependent seizure susceptibility (Terasawa and Timiras, 1968; Buterbaugh and Hudson, 1991), circumstances that involve substantial NMDA receptor activation.

Our results may also help to explain a puzzling dichotomy in the effects of estrogen on the susceptibility of female rats to kainic acid-induced seizures, which depend in part on hippocampal activity (Ben-Ari et al., 1981; Lothman and Collins, 1981). Woolley (2000) found that a slightly lower proportion of $48^{2} \mathrm{E}$ than $48^{2} \mathrm{O}$ rats developed behavioral seizures when treated with kainic acid; however, when seizures were initiated, they progressed more rapidly and were more severe in $48^{2} \mathrm{E}$ than in $48^{2} \mathrm{O}$ animals. It is conceivable that the slight protective effect of estrogen on seizure initiation is caused by enhanced synaptic inhibition of hippocampal pyramidal cells. However, after the barrier of greater inhibition in $48^{2} \mathrm{E}$ is overcome, enhanced sensitivity to excitatory input makes hippocampal neurons more prone to developing and propagating synchronous discharge associated with seizure activity.

\section{REFERENCES}

Banks MI, White JA, Pearce RA (2000) Interactions between distinct GABA $_{\mathrm{A}}$ circuits in hippocampus. Neuron 25:449-457.

Ben-Ari Y, Tremblay E, Riche D, Ghilini G, Naquet R (1981) Electrographic, clinical and pathological alterations following systemic administration of kainic acid, bicuculline or pentetrazole: metabolic mapping using the deoxyglucose method with special reference to the pathology of epilepsy. Neuroscience 6:1361-1391.

Bowers G, Cullinan WE, Herman JP (1998) Region-specific regulation of glutamic acid decarboxylase (GAD) mRNA expression in central stress circuits. J Neurosci 18:5938-5947.

Buterbaugh GG, Hudson GM (1991) Estradiol replacement to female rats facilitates dorsal hippocampal but not ventral hippocampal kindled seizure acquisition. Exp Neurol 111:55-64.

Churchill L, Taishi P, Guan Z, Chen L, Fang J, Krueger JM (2001) Sleep modifies glutamate decarboxylase mRNA within the barrel cortex of rats after a mystacial whisker trim. Sleep 24:261-266.

Cordoba-Montoya DA, Carrer HF (1997) Estrogen facilitates induction of long-term potentiation in the hippocampus of awake rats. Brain Res 778:430-438.

Erlander MG, Tobin AJ (1991) The structural and functional heterogeneity of glutamic acid decarboxylase: a review. Neurochem Res 16:215-226.

Erlander MG, Tillakaratne NJ, Feldblum S, Patel N, Tobin AJ (1991) Two genes encode distinct glutamate decarboxylases. Neuron 7:91-100.
Freund TF, Buzsaki G (1996) Interneurons of the hippocampus. Hippocampus 6:347-470.

Gazzaley AH, Weiland NG, McEwen BS, Morrison JH (1996) Differential regulation of NMDAR1 mRNA and protein by estradiol in the rat hippocampus. J Neurosci 16:6830-6838.

Gonzales C, Kaufman DL, Tobin AJ, Chesselet MF (1991) Distribution of glutamic acid decarboxylase $(\mathrm{Mr} \mathrm{67,000)}$ in basal ganglia of the rat: an immunohistochemical study with a selective cDNA-generated polyclonal antibody. J Neurocytol 20:953-961.

Gould E, Woolley CS, Frankfurt M, McEwen BS (1990) Gonadal steroids regulate dendritic spine density in hippocampal pyramidal cells in adulthood. J Neurosci 10:1286-1291.

Gundersen HJG, Bagger P, Bendtsen TF, Evans SM, Korbo L, Marcussen N, Moller A, Nielsen K, Nyengaard JR, Pakkenberg B, Sorensen FB, Vesterby A, West MJ (1988) The new stereological tools: disector, fractionator, nucleator and point sampled intercepts and their use in pathological research and diagnosis. APMIS 96:857-881.

Harris KM (1999) Structure, development, and plasticity of dendritic spines. Curr Opin Neurobiol 9:343-348.

Hart SA, Woolley CS (2000) Colocalization of ER- $\alpha$ and GAD immunoreactivity in the CA1 region of the adult female rat hippocampus. Soc Neurosci Abstr 26:1148.

Houser CR, Esclapez M (1994) Localization of mRNAs encoding two forms of glutamic acid decarboxylase in the rat hippocampal formation. Hippocampus 4:530-545.

Jones KJ, McEwen BS, Pfaff DW (1988) Quantitative assessment of early and discontinuous estradiol-induced effects on ventromedial hypothalamic and preoptic area proteins in female rat brain. Neuroendocrinology 48:561-568.

Jones KJ, Harrington CA, Chikaraishi DM, Pfaff DW (1990) Steroid hormone regulation of ribosomal RNA in rat hypothalamus: early detection using in situ hybridization and precursor-product ribosomal DNA probes. J Neurosci 10:1513-1521.

Kaufman DL, Houser CR, Tobin AJ (1991) Two forms of the gammaaminobutyric acid synthetic enzyme glutamate decarboxylase have distinct intraneuronal distributions and cofactor interactions. J Neurochem 56:720-723.

Kunkel DD, Lacaille JC, Schwartzkroin PA (1988) Ultrastructure of stratum lacunosum-moleculare interneurons of hippocampal CA1 region. Synapse 2:382-394.

Lacaille JC, Schwartzkroin PA (1988) Stratum lacunosum-moleculare interneurons of hippocampal CA1 region. II. Intrasomatic and intradendritic recordings of local circuit synaptic interactions. J Neurosci 8:1411-1424.

Leranth C, Shanabrough M, Horvath TL (2000) Hormonal regulation of hippocampal spine density involves subcortical mediation. Neuroscience 101:349-356.

Lothman EW, Collins RC (1981) Kainic acid induced limbic seizures: metabolic, behavioral, electroencephalography and neuropathological correlates. Brain Res 218:299-318.

Martin DL, Martin SB, Wu SJ, Espina N (1991) Cofactor interactions and the regulation of glutamate decarboxylase activity. Neurochem Res 16:243-249

McEwen BS, Tanapat P, Weiland NG (1999) Inhibition of dendritic spine induction on hippocampal CA1 pyramidal neurons by a nonsteroidal estrogen antagonist in female rats. Endocrinology 140:1044-1047.

Murphy DD, Segal M (1996) Regulation of dendritic spine density in cultured rat hippocampal neurons by steroid hormones. J Neurosci 16:4059-4068.

Murphy DD, Cole NB, Greenberger V, Segal M (1998) Estradiol increases dendritic spine density by reducing GABA neurotransmission in hippocampal neurons. J Neurosci 18:2550-2559.

Pearce RA (1993) Physiological evidence for two distinct $\mathrm{GABA}_{\mathrm{A}}$ responses in rat hippocampus. Neuron 10:189-200.

Sloviter RS, Dichter MA, Rachinsky TL, Dean E, Goodman JH, Sollas AL, Martin DL (1996) Basal expression and induction of glutamate decarboxylase and GABA in excitatory granule cells of the rat and monkey hippocampal dentate gyrus. J Comp Neurol 373:593-618.

Smart FM, Halpain S (2000) Regulation of dendritic spine stability. Hippocampus 10:542-554

Smith SS, Gong QH, Hsu FC, Markowitz RS, ffrench-Mullen JM, Li X (1998) GABA(A) receptor alpha4 subunit suppression prevents withdrawal properties of an endogenous steroid. Nature 392:926-930.

Soghomonian JJ, Martin DL (1998) Two isoforms of glutamate decarboxylase: why? Trends Pharmacol Sci 19:500-505.

Stone DJ, Walsh J, Benes FM (1999) Localization of cells preferentially expressing $\mathrm{GAD}_{67}$ with negligible $\mathrm{GAD}_{65}$ transcripts in the rat hippocampus. A double in situ hybridization study. Brain Res Mol Brain Res 71:201-209.

Szabo G, Kartarova Z, Hoertnagl B, Somogyi R, Sperk G (2000) Differential regulation of adult and embryonic glutamate decarboxylases in rat dentate granule cells after kainate-induced limbic seizures. Neuroscience 100:287-295.

Terasawa E, Timiras PS (1968) Electrical activity during the estrous 
cycle of the rat: cyclical changes in limbic structures. Endocrinology 83:207-216.

Weiland NG (1992) Estradiol selectively regulates agonist binding sites on the $N$-methyl-D-aspartate receptor complex in the CA1 region of the hippocampus. Endocrinology 131:662-668.

Weiland NG, Orikasa C, Hayashi S, McEwen BS (1997) Distribution and hormone regulation of estrogen receptor immunoreactive cells in the hippocampus of male and female rats. J Comp Neurol 388:603-612.

Wong M, Moss RL (1992) Long-term and short-term electrophysiological effects of estrogen on synaptic properties of hippocampal CA1 neurons. J Neurosci 12:3217-3225.

Woolley CS (2000) Estradiol facilitates kainic acid-induced, but not flurothyl-induced, behavioral seizure activity in adult female rats. Epilepsia 41:510-515.

Woolley CS, McEwen BS (1992) Estradiol mediates fluctuation in hip- pocampal synapse density during the estrous cycle in the adult rat. J Neurosci 12:2549-2554

Woolley CS, McEwen BS (1993) Roles of estradiol and progesterone in regulation of hippocampal dendritic spine density during the estrous cycle in the rat. J Comp Neurol 336:293-306.

Woolley CS, McEwen BS (1994) Estradiol regulates hippocampal dendritic spine density via a $N$-methyl-D-aspartate receptor-dependent mechanism. J Neurosci 14:7680-7687.

Woolley CS, Wenzel HJ, Schwartzkroin PA (1996) Estradiol increases the frequency of multiple synapse boutons in the hippocampal CA1 region of the adult female rat. J Comp Neurol 373:108-117.

Woolley CS, Weiland NG, McEwen BS, Schwartzkroin PA (1997) Estradiol increases the sensitivity of hippocampal CA1 pyramidal cells to NMDA receptor-mediated synaptic input: correlation with dendritic spine density. J Neurosci 17:1848-1859. 